\title{
ATRACTOSTEUS SPATULA (ACTINOPTERYGII: LEPISOSTEIFORMES: LEPISOSTEIDAE): A DELIBERATE AQUARIUM TRADE INTRODUCTION INCIDENCE IN THE SHATT AL-ARAB RIVER, BASRAH, IRAQ
}

\author{
Falah MUTLAK ${ }^{1}$, Laith JAWAD², and Abbas AL-FAISAL ${ }^{1}$ \\ ${ }^{1}$ Marine Science Centre, University of Basrah, Basrah, Iraq \\ ${ }^{2}$ Flat Bush, Manukau, Auckland, New Zealand
}

\begin{abstract}
Mutlak F., Jawad L., Al-Faisal A. 2017. Atractosteus spatula (Actinopterygii: Lepisosteiformes: Lepisosteidae): A deliberate aquarium trade introduction incidence in the Shatt al-Arab River, Basrah, Iraq. Acta Ichthyol. Piscat. 47 (2): 205-207.
\end{abstract}

\begin{abstract}
The first record of a single specimen of alligator gar, Atractosteus spatula (Lacepède, 1803), native to North America, is reported from the inland waters of Iraq. The specimen was caught from southern reaches of the Shatt al-Arab River at Om-al-Rasas Island, Basrah, Iraq during an ichthyologic survey in September 2016 using gillnets with mesh size of $40 \mathrm{~mm}$. The capture of a sub-adult specimen, $900 \mathrm{~mm}$ in total length, marks the first record of a member of the family Lepisosteidae in the freshwater system of Iraq. Aquarium trade pathway is the suspected factor for the presence of this species in the Iraqi freshwater area.
\end{abstract}

Keywords: biodiversity, new locality, new occurrence, aquarium trade, invasion

The introduction of exotic species, is widely considered to be the second most important cause of species extinction after habitat destruction (Simberloff 2003). Acosta and Gupta (2005) suggested that exotic fishes have been deliberately introduced primarily to enhance fisheries and aquaculture production. Fishes may be also introduced to support recreational fishery activities in developed countries. Other main reasons include pest control, research activities, and aquarium trade (Cohen et al. 2007, Chang et al. 2009).

Basrah Province, Iraq has many aquatic resources including coastal waters, marshes, and rivers, which are potentially a suitable environment for exotic fish species capable of surviving the local environmental conditions. With the absence of regulations on importing fish species and deficiencies in the knowledge on the biology of the fish species being imported by the aquarium trade in Iraq, such events give the chance for unfavourable fish species to be included to the freshwater system of Iraq.

The only exotic fish introduction via aquarium trade reported from the marshes of central Iraq is Pangasianodon hypophthalmus (Sauvage, 1878) (see Khamees et al. 2013), Mollienesia latipinna (Lesueur, 1821) (see Al-Faisal and Mutlak 2014). The same species were also mentioned by Al-Lamy et al. (2012) and Mohamed et al. (2008).

A single specimen of alligator gar, Atractosteus spatula (Lacepède, 1803), native to North America, was captured from southern reaches of the Shatt al-
Arab River at Om-al-Rasas Island, Basrah, Iraq $\left(30^{\circ} 30^{\prime} 04.56^{\prime \prime} \mathrm{N} ; 47^{\circ} 51^{\prime} 57.18^{\prime \prime} \mathrm{E}\right)$ during a fish survey in the Shatt al-Arab River basin. The aim of this study was to report the presence of $A$. spatula in the inland waters of Iraq and discuss the possible impact of the introduction of this exotic species on the native fish fauna of the area. The fish specimen was captured in September 2016 using gillnets with mesh size of $40 \mathrm{~mm}$. The specimen was identified according to Page and Burr (2011) and deposited in the fish collection at the Marine Science Centre, University of Basrah, Iraq (MSC 00132). The nomenclature follows Eschmeyer et al. (2017). A series of morphometric measurements were made with a ruler to the nearest $1 \mathrm{~mm}$ following the methods of Wiley (1976) (Table 1). Gonads were examined using laboratory microscope.

Atractosteus spatula can be distinguished from the other members of the family Lepisosteidae in having a large, round body, with an elongated, but relatively broad snout (Figs. 1 and 2). The fish examined was an immature male, with gonad weight of $85.9 \mathrm{~g}$.

The total length of our specimen $(900 \mathrm{~mm})$ is less than the common total length given for this species $(2000 \mathrm{~mm})$ (Wiley 1978).

The alligator gar can be harmful if it becomes a successful invasive species and it is capable of creating a sustainable population. Alligator gar feeds mainly on fishes and it is a successful predator in its native environment. The eggs of alligator gar are poisonous, 
but their consumption by people is unlikely (Boschung and Mayden 2004, Goddard 2009). Additionally, this fish could damage fishing nets due to the shape of its head and the sharp teeth.

There has been no published information about established population alligator gar outside its native America. The nearest locality where alligator gar has been reported is the Caspian Sea coasts of Turkmenistan (Salinkov 2010). Considering the substantial distance the possible migration of the fish to Iraq seems to be unlikely. It is difficult to tell precisely how this specimen was introduced and how it penetrated into the Shatt alArab River of Iraq, but it is known that these fish are kept in aquaria all over the world. Recently, the aquarium

Table 1

Biometric characters of Atractosteus spatula collected from Shatt al-Arab River, Basrah, Iraq

\begin{tabular}{lcc}
\hline \multicolumn{1}{c}{ Character } & Absolute value & Relative value \\
\hline Weight & $5252 \mathrm{~g}$ & \\
Total length (TL) & $900 \mathrm{~mm}$ & \\
Standard length (SL) & $780 \mathrm{~mm}$ & $86.7 \%$ in TL \\
Body depth & $130 \mathrm{~mm}$ & $16.7 \%$ in SL \\
Head length (HL) & $245 \mathrm{~mm}$ & $31.4 \%$ in SL \\
Head depth & $74.8 \mathrm{~mm}$ & $30.5 \%$ in HL \\
Head width & $82.1 \mathrm{~mm}$ & $33.5 \%$ in HL \\
Snout length & $128 \mathrm{~mm}$ & $52.2 \%$ in HL \\
Eye diameter & $19.9 \mathrm{~mm}$ & $8.1 \%$ in HL \\
Interorbital distance & $66.6 \mathrm{~mm}$ & $27.2 \%$ in HL \\
Dorsal fin length & $46.8 \mathrm{~mm}$ & $6.1 \%$ in SL \\
Pectoral fin length & $75.3 \mathrm{~mm}$ & $9.7 \%$ in SL \\
Pelvic fin length & $78.8 \mathrm{~mm}$ & $10.1 \%$ in SL \\
Anal fin length & $47.3 \mathrm{~mm}$ & $6.1 \%$ in SL \\
Predorsal fin length & $670 \mathrm{~mm}$ & $85.9 \%$ in SL \\
Postdorsal fin length & $735 \mathrm{~mm}$ & $94.2 \%$ in SL \\
Dorsal fin rays & 7 & \\
Anal fin rays & 7 & \\
Pectoral fin rays & 14 & \\
Pelvic fin rays & 7 & \\
Lateral line scales & 60 & \\
\hline
\end{tabular}

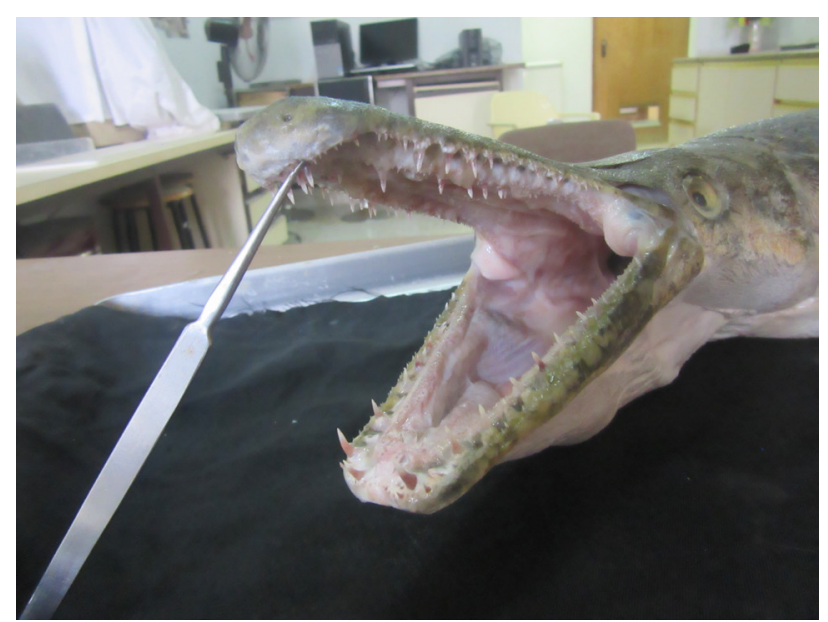

Fig. 1. Atractosteus spatula, $900 \mathrm{~mm}$ TL, collected from Shatt al-Arab River, Basrah, Iraq, mouth view trade in Iraq has become very popular with the easing of regulations importing fishes into Iraq, and increase of aquarium shops (personal observation). Alligator gars are sold in these shops, mainly in large cities like Baghdad and Basrah. Aquarists frequently get rid of unwanted fish by releasing them into open water bodies. It is also likely that alligator gars are released, because of their substantial annual length increment of 250-300 mm (Boschung and Mayden 2004, Roberts and Harrel 2009).

The presently reported finding represents the third Iraqi case of the exotic species introduction, blamed on aquarium trade.

\section{REFERENCES}

Acosta B.O., Gupta M.V. 2005. The status of introduced carp species in Asia. Pp. 121-1230. In: Penman D.J., Gupta M.V. (eds.) Carp genetic resources for aquaculture in Asia, World Fish Centre, Penang, Malaysia.

Al-Faisal A.J., Mutlak F.M. 2014. First record of the Nile tilapia Oreochromis niloticus (Linnaeus, 1758), from the Shatt al-Arab River, southern Iraq. Mesopotamian Journal of Marine Science 29 (1): 45-50.

Al-Lamy J.H., ResenA.K., Taher M.M., Muhammed S.J. 2012. Specialization and diet overlapped between two alien species (Carassius auratus and Tilapia zillii) and native species (Barbus luteus) in East Hammar Marsh, southern Iraq. Journal of King Abdulaziz University Marine Sciences 23 (2): 25-37.

DOI: 10.4197/Mar.23-2.2

Boschung H.T., Mayden R.L. 2004. Fishes of Alabama. Smithsonian Institution Press, Washington DC, USA.

Chang A.L., Grossman J.D., Spezio T.S., Weiskel H.W., Blum J.C., Burt J.W., Muir A.A., Piovia-Scott J., Veblen K.E., Grosholz E.D. 2009. Tackling aquatic invasions: Risks and opportunities for the aquarium fish industry. Biological Invasions 11 (4): 773-785. DOI: $\underline{10.1007 / \mathrm{s} 10530-008-9292-4}$

Cohen J., Mirotchnick N., Leung B. 2007. Thousands introduced annually: the aquarium pathway for nonindigenous plants to the St Lawrence Seaway. Frontiers in the Ecology and the Environment 5 (10): 528-532. DOI: $10.1890 / 060137$

Eschmeyer W.N., Fricke R., van der Laan R. (eds.) 2017. Catalog of fishes: Genera, species, references. California Academy of Sciences, San Francisco, USA. http:// researcharchive.calacademy.org/research/ichthyology/ catalog/fishcatmain.asp [Accessed on 4 March 2017.]

Goddard N. 2009. Alligator gar. Ichthyology at the Florida Museum of Natural History. https://www. floridamuseum.ufl.edu/fish/discover/species-profiles/ atractosteus-spatula

Khamees N.R., Ali A.H., Abed J.M., Adday T.K. 2013. First record of striped catfish Pangasianodon hypophthalmus (Sauvage, 1878) (Pisces: Pangasiidae) from inland waters of Iraq. Basrah Journal of Agricultural Sciences 26 (Special issue 1): 178-183.

Mohamed A.-R.M., Hussain N.A., Al-Noor S.S., Mutlak F.M., Sudani I.M., Mojer A.M., Toman 


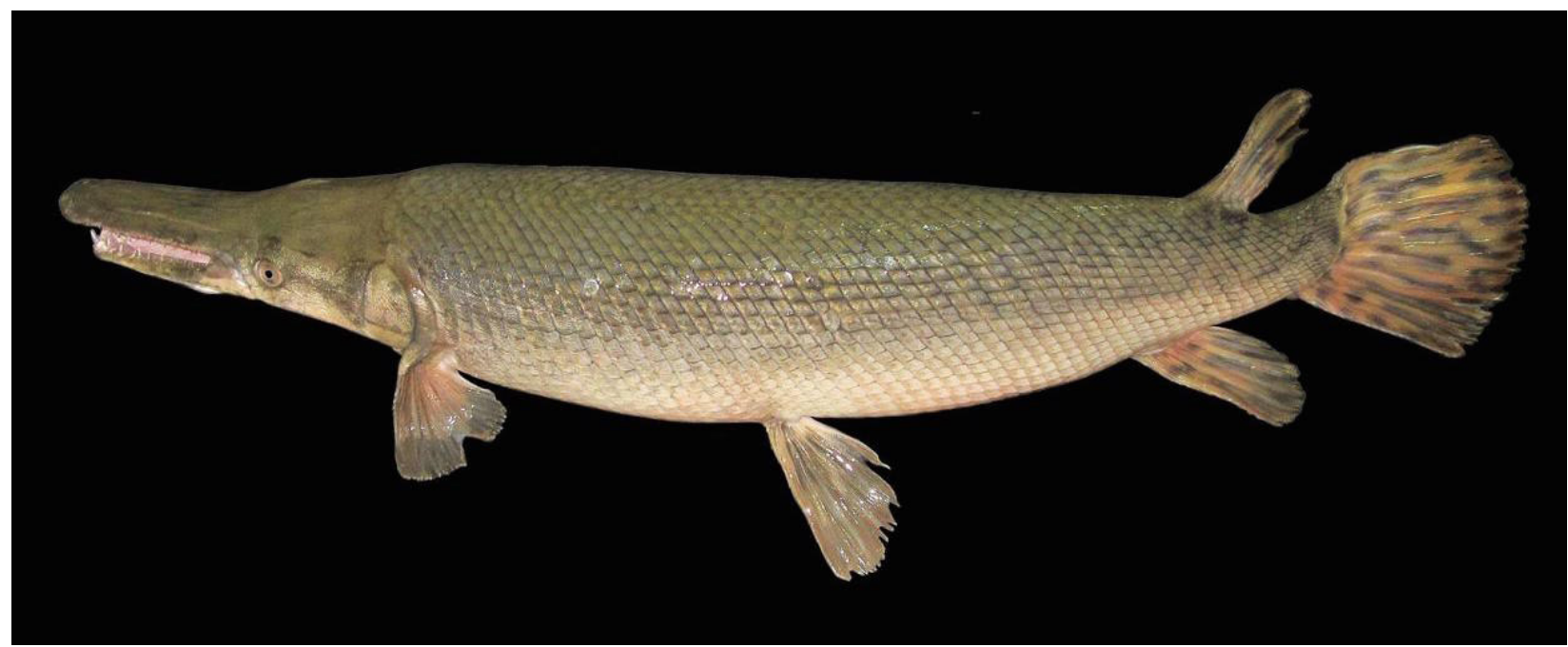

Fig. 2. Atractosteus spatula, $900 \mathrm{~mm}$ TL collected from Shatt al-Arab River, Basrah, Iraq; lateral view

A.J., Abdad M.A. 2008 Fish assemblage of restored Al-Hawizeh marsh, southern Iraq. Ecohydrology and Hydrobiology 8 (2-4): 375-384.

DOI: $10.2478 / \mathrm{v} 10104-009-0029-5$

Page L.M., Burr B.M. 1991. Freshwater fishes: A field guide to freshwater fishes of North America north of Mexico. Peterson Field Guide Series. Houghton Mifflin, Boston MA, USA.

Roberts D., Harrel S. 2006. Atractosteus spatula gemfish. Animal Diversity Web, University of Michigan, Museum of Zoology. http://animaldiversity. org/accounts/Atractosteus spatula

Salnikov V.B. 2010. First finding of gar Atractosteus sp. (Actinopterygii, Lepisosteiformes, Lepisosteidae) in the Caspian Sea near the coast of Turkmenistan. Russian Journal of Biological Invasion 1 (1): 17-20. DOI: $10.1134 / \mathrm{S} 2075111710010042$

Simberloff D. 2003. Confronting introduced species: A form of xenophobia? Biological Invasions 5 (3): 179192.

DOI: $10.1023 / \mathrm{A}: 1026164419010$

Wiley E.O. 1976. The phylogeny and biogeography of fossil and recent gars (Actinopterygii: Lepisosteidae). University of Kansas Museum of Natural History, Miscellaneous Publication 64: 1-111.

Wiley E.O. 1978. Lepisosteidae. In: Fischer W. (ed.) FAO species identification sheets for fishery purposes. Western Central Atlantic (Fishing Area 31). Vol. 3. FAO, Rome.

Received: 19 December 2016 Accepted: 17 March 2017 Published electronically: 30 June 2017 
